\title{
Mineral Trioxide Aggregate and Calcium Hydroxide Promotes In Vivo Intratubular Mineralization
}

\section{El agregado de trióxido mineral y el hidróxido de calcio promueven mineralización intratubular In Vivo}

Mabel M. Cordeiro, DDS, PhD'; Adair S. Santos PhD²; Jessie F. Reyes Carmona DDS, MSD, PhD³

1. Department of Morphological Sciences, Federal University of Santa Catarina, SC, Brazil.

2. Department of Physiological Sciences, Federal University of Santa Catarina, SC, Brazil.

3. Faculty of Dentistry, University of Costa Rica, San José, Costa Rica.

Correspondence to: Dra. Jessie Reyes Carmona - jessie.reyes@ucr.ac.cr

Received: 1-II-2016

Accepted: 10-|II-2016

Published Online First: 15-III-2016

DOI: http://dx.doi.org/10.15517/ijds.v0i0.23548

\section{ABSTRACT}

Literature showed that the interaction of Mineral Trioxide Aggregate (MTA) with dentin in phosphate-buffered saline (PBS) promotes a biomineralization process that leads to the formation of an interfacial layer with mineralized structures at the cement-dentin interface. Thus, we investigated the in vivo biomineralization process promoted by $\mathrm{MTA}$ and $\mathrm{Ca}(\mathrm{OH})^{2}$ with dentin. Human dentin tubes filled with ProRoot MTA, $\mathrm{Ca}(\mathrm{OH})^{2}$ or kept empty were implanted in subcutaneous tissues in the back of mice. After $12 \mathrm{~h}, 1,3,7,15,30$ and 60 days, the dentin tubes were processed for Scanning Electron Microscope (SEM) observations. SEM examination showed the presence of apatite-like clusters on collagen fibrils over the surface of tubes containing the biomaterials. This mineral deposition was more extensive and compact through time. At day 7 , a compact layer of apatite was formed. The MTA/Ca(OH) ${ }^{2}$-dentin interface showed intratubular mineralization as early as $12 \mathrm{~h}$ post-implantation. MTA and $\mathrm{Ca}(\mathrm{OH})^{2}$ in an in vivo environment promoted a biomineralization process with dentin, simultaneously to the acute inflammatory response. MTA triggered an earlier and denser interfacial layer.

\section{KEYWORDS}

Apatite; Bioactivity; Biomineralization; Calcium hydroxide $\left(\mathrm{Ca}(\mathrm{OH})^{2}\right)$; Mineral Trioxide Aggregate (MTA). 


\section{RESUMEN}

Previos reportes de literatura demostraron la interacción del agregado de trióxido mineral (MTA) con la dentina en solución salina tamponada con fosfato (PBS), la cual promueve un proceso de biomineralización que resulta en la formación de una sedimentación de apatita carbonatada y la mineralización de fibras colágenas intratubulares en la interface cemento-dentina. Por lo tanto, se investigó el proceso de biomineralización in vivo promovido por el MTA y el hidróxido de calcio $\left(\mathrm{Ca}(\mathrm{OH})^{2}\right)$ con la dentina. Así, tubos de dentina humanos obturados con ProRoot $\mathrm{MTA}, \mathrm{Ca}(\mathrm{OH})^{2}$ o vacíos fueron implantados en el tejido subcutáneo de ratones. Después de 12h, 1, 3, 7, 15, 30 y 60 días, los tubos de dentina se procesaron para microscopía electrónica de barrido (MEB). La evaluación en MEB demostró la presencia de grupos similares a los previamente reportados como apatita en las fibrillas de colágeno sobre la superficie de los tubos que contienen los biomateriales. Esta deposición mineral era más extensa y compacta a través del tiempo. Al día 7, se formó una capa compacta de apatita. La interface entre el MTA/Ca $(\mathrm{OH})^{2}$ presentó mineralización intratubular desde las primeras 12 horas post-implantación. El MTA y el $\mathrm{Ca}(\mathrm{OH})^{2}$ en un ambiente in vivo promovieron un proceso de biomineralización con la dentina, simultáneamente a la respuesta inflamatoria aguda. El MTA promueve un proceso de biomineralización expedito y más denso.

\section{PALABRAS CLAVE}

Apatita; Bioactividad; Biomineralización; Hidróxido de Calcio $\left(\mathrm{Ca}(\mathrm{OH})^{2}\right)$; Agregado de Trióxido Mineral (MTA).

\section{INTRODUCTION}

Mineral Trioxide Aggregate (MTA) and Calcium Hydroxide $\left(\mathrm{Ca}(\mathrm{OH})^{2}\right)$ have been used extensively as promising biomaterials for stimulating dentinogenesis and cementogenesis $(1,2)$. Despite its wide use in clinical practice, the mechanism of action in the induction of hard tissue deposition is still unknown.

Recent studies suggested that MTA may modulate tissue repair and hard tissue deposition due to its ability to promote carbonate apatite deposition $(3,5)$. MTA releases calcium hydroxide, which interacts with a phosphate-containing fluid to produce calcium-deficient apatite via an amorphous calcium phosphate phase $(3,4)$. The apatite formed by the MTA-PBS system was deposited among collagen fibrils, promoting controlled mineral nucleation on dentin, triggering the formation of an interfacial layer with tag-like structures at the cement-dentin interface $(4,5)$. This biomineralization process promoted in the MTA-dentin interface enhances the push-out bond strength of the cement with dentin (5).

A previous in vivo study showed that MTA induced apatite deposition simultaneously to the acute inflammatory response (6). Probably, MTA ability to promote apatite precipitates during the acute phase of inflammation may signal several unrecognized pathways in different cell types in order to contribute in repair and biomineralization.

Studies comparing MTA with $\mathrm{Ca}(\mathrm{OH})^{2}$ have proposed that both biomaterials have a similar mechanism of action $(7,9)$. However, it is still unknown if $\mathrm{Ca}(\mathrm{OH})^{2}$ has the ability to promote a biomineralization process with dentin. Moreover, up-to-date, there is no studies analyzing if $\mathrm{Ca}(\mathrm{OH})^{2}$ have the ability to promote in an in vivo environment the formation of the interfacial 
layer with tag-like structures at the biomaterialsdentin interface. Thus, we evaluated the in vivo biomineralization process promoted by MTA and $\mathrm{Ca}(\mathrm{OH})^{2}$ with dentin.

\section{MATERIALS AND METHODS}

All experimental protocols used in this study were approved by the Animal Ethics Screening Committee and the Ethics Committee for Research with Human Beings of the Federal University of Santa Catarina (UFSC, Florianópolis, Santa Catarina, Brazil).

Seventy dentin tubes were prepared according to the procedure previously described (6). After being autoclaved, the tubes were thoroughly irrigated with $17 \%$ ethylenediaminetetraacetic acid (EDTA) and $1 \%$ sodium hypochlorite and, then filled with Tooth-colored ProRoot MTA (Dentsply, Tulsa Dental, OK, USA), $\mathrm{Ca}(\mathrm{OH})^{2}$ (MERCK, Germany) or kept empty to be used as controls.

Male Swiss mice (35-40 g) were anesthetized with ketamine hydrochloride (Dopalen, Division Vetbrands Animal Health, Jacareí, SP, Brazil) and xylazine (Anasedan, Agribrands do Brasil Ltda, Paulínia, SP, Brazil). The filled and empty dentin tubes were implanted in the subcutaneous tissue in the backs of mice, at least $1 \mathrm{~cm}$ away from each other. Each mouse received 1 dentin tube filled with $\mathrm{MTA}, 1$ with $\mathrm{Ca}(\mathrm{OH})^{2}$ and 1 empty, ensuring a rotation of sites.

After $12 \mathrm{~h}, 1,3,7,15,30$ and 60 days of implantation, the animals were euthanized and the tubes were removed and fixed in 2.5\% glutaraldehyde buffered with $0.2 \mathrm{~mol} / \mathrm{L}$ of sodium cacodylate for $12 \mathrm{~h}$ at $4^{\circ} \mathrm{C}$.

After fixation, the dentin tubes were washed in buffer solution and divided in order to be processed by two different protocols for SEM observation. Half of the dentin tubes were dehydrated in ascending grades of ethanol and, the other half of dentin tubes were processed for SEM observation as previously describe by Reyes-Carmona et al. (4). The specimens were mounted on aluminum stubs and sputter-coated with a $300-A^{\circ}$ gold layer. They were then observed under a SEM (Philips SEM XL 30 ) at an accelerating voltage of $10 \mathrm{kV}$. The surface of dentin tubes and the biomaterial-dentin interface was examined at different magnifications (2501000X) to verify the formation of an interfacial layer and/or the presence of intratubular mineralization. When mineral deposition was evident, its elemental composition was investigated by EDAX with SEM (Philips SEM XL 30).

\section{RESULTS}

SEM examination of the surface of dentin tubes filled with MTA and $\mathrm{Ca}(\mathrm{OH})^{2}$ showed the presence of apatite-like clusters (Fig.1). SEM photomicrographs revealed apatite-like crystallites deposition on tissue collagen fibrils. On day 1 , apatite deposition was greater and the collagen fibrils in the more highly mineralized region exhibited a "corn-on-the-cob" appearance (10) (Fig. 1B,C). As the implantation time increased, these precipitates formed agglomerates denoting a more extensive mineralization (Fig. 1D). 


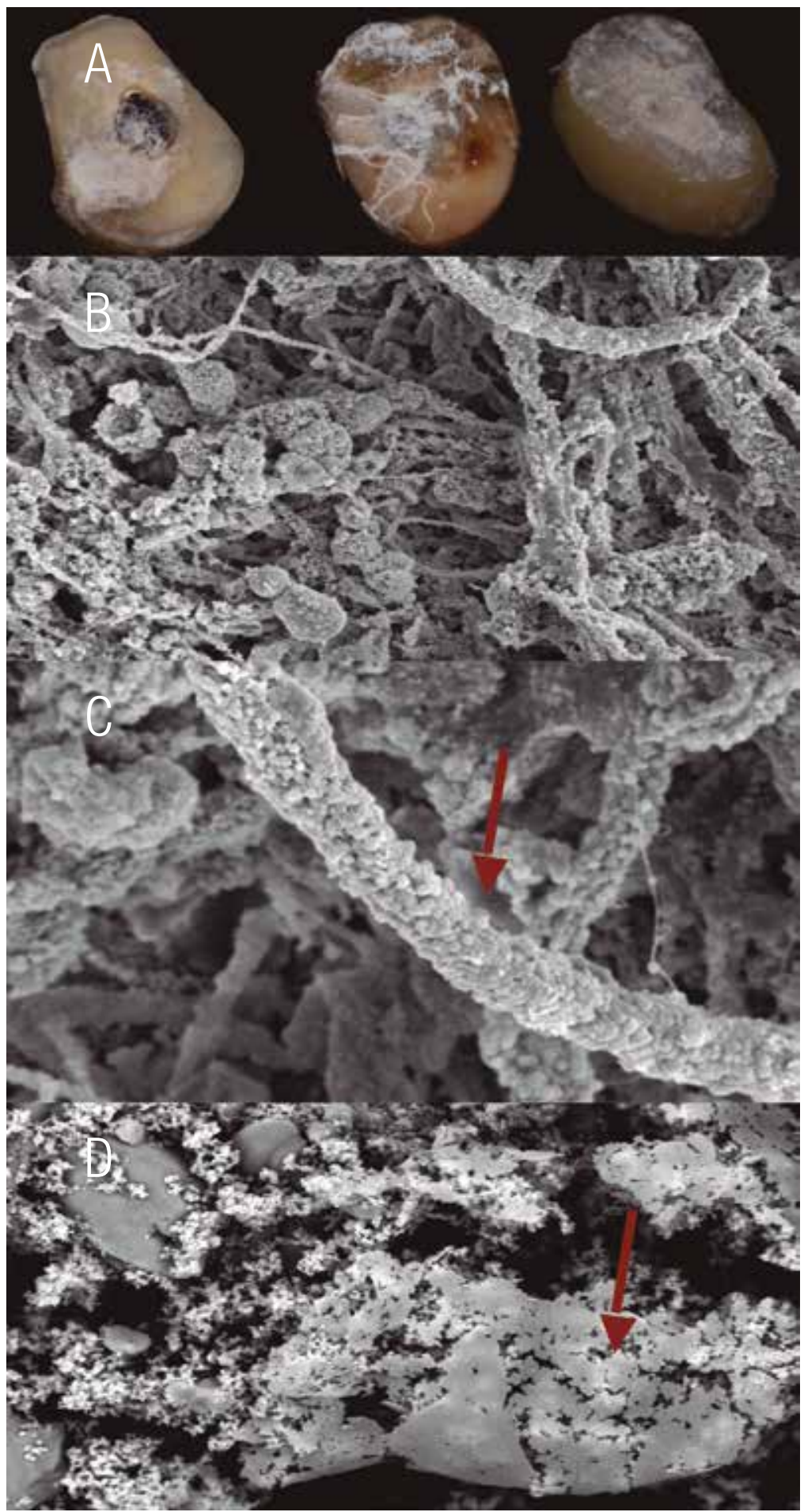

Figure 1. SEM photomicrographs of the surface of dentin tubes filled with ProRoot MTA after subcutaneous implantation. (A) Formation of several apatite-like precipitates at day 1. (B) Observe the deposition of several apatite clusters on the collagen fibers (1500x). (C) Increased deposition of precipitates at day 1, and in areas of higher mineralization, collagen fibers exhibited a typical "corn-on-the-cob" appearance (red arrow) (5000x). (D) Mineralization areas were more extensive and compact as the implantation time increased (1500x). 
On examination of the biomaterialdentin interface, it was possible to differentiate the biomineralization ability of each material with dentin. MTA-dentin interface showed an intratubular mineralization process, as early as $12 \mathrm{~h}$ post-implantation (Fig. 2). The tag-like structures (TS) resembling demineralized tubular dentin were observed extending from the interfacial layer and seemed like these structures grew in size, becoming more compact and denser over time (Fig. 2). Interestingly, the intratubular mineralization process was not limited to the MTAdentin interface, as it was possible to observe this phenomenon all over the dentin surface (Fig.3).

Until the third day, it was not possible to observe the intratubular mineralization process on $\mathrm{Ca}(\mathrm{OH})^{2}$-dentin interface. In some samples, even after 3 days, it was difficult to observe the presence of an interfacial layer (Fig. 4). On days 15,30 and 60 , it was shown the presence of fewer TS, suggesting that $\mathrm{Ca}(\mathrm{OH})^{2}$ promotes a lesser and deficient biomineralization process with dentin in comparison with MTA. SEM photomicrographs of the empty tubes demonstrated no intratubular mineralization (Fig. 5).

\section{DISCUSSION}

The exact mechanism of action of MTA and $\mathrm{Ca}(\mathrm{OH})^{2}$ remains elusive $(11,15)$. Thus, this study was carried out to analyze the biomineralization process promoted by MTA and $\mathrm{Ca}(\mathrm{OH})^{2}$ with dentin and its relationship with the resolution of the inflammatory reaction, in order to comprehend the host response to MTA and $\mathrm{Ca}(\mathrm{OH})^{2}$.

SEM analyses of dentin tubes filled with the biomaterials showed the presence of apatite-like clusters deposition on collagen fibrils, as soon as $12 \mathrm{~h}$ post-implantation. SEM-EDAX indicated that the precipitates are mainly composed by calcium and phosphorus. Previously, we have shown that the interaction of MTA with dentin in a phosphate containing fluid produce an amorphous calcium phosphate phase, which act as precursor during the formation of carbonated apatite (4). It is important to highlight that SEM EDAX analysis for precipitates formed by MTA and $\mathrm{Ca}(\mathrm{OH})^{2}$ after subcutaneous implantation displayed similar results (Fig.2). Past studies suggested that the calcium ions released by MTA and $\mathrm{Ca}(\mathrm{OH})^{2}$ react with the carbon dioxide from the tissue, giving rise to granulations of calcite crystals $(6,8,15$, 16). However, these studies never employed methodologies aiming to characterize these dystrophic calcifications. In vitro studies employing simulated body fluid are more indicated when aiming precipitates characterization, because of the difficulty of obtainment the crystals in an "in vivo environment" (17). Previous in vitro studies suggested that calcium ions released by MTA react with phosphate in PBS, yielding hydroxyapatite precipitates $(16,19)$. However, it is well known that stoichiometric hydroxyapatites do not exist in biological systems. Indeed, it was recognized that the intermediate key that precedes the appearance of biological calcified tissues is amorphous calcium phosphate $(3,19,20)$. Taken together, the data from previous studies, our preceding in vitro findings and the results of this study, it can be suggested that in an in vivo environment, MTA and $\mathrm{Ca}(\mathrm{OH})^{2}$ promotes carbonated apatite deposition.

Our data revealed apatite-like crystallites deposition on tissue collagen fibrils. As the implantation time increased, this deposition was higher and it seemed like precipitates grew in size. At higher magnification, numerous amorphous calcium phosphate spheres along the surface of the collagen fibrils suggested the presence of a mineral support within collagen fibrils. On day 3 , collagen fibrils in the more highly mineralized regions exhibited the "corn-on-the-cob" appearance, which is suggestive of interfibrillar mineralization (10). This mineral deposition and maturation increased over time and on day 7 , a formed layer completely covered the surface of the dentin tubes. 
SEM analysis of MTA-dentin interface revealed the presence of mineralized structures as soon as $12 \mathrm{~h}$. This intratubular mineralization seemed to get more mature and greater over time. Despite similarities in the mechanism of action on tissue by both biomaterials, $\mathrm{Ca}(\mathrm{OH})^{2}$ showed a lesser and fewer delayed intratubular mineralization. One possible explanation is that $\mathrm{Ca}(\mathrm{OH})^{2}$ paste has a high solubility avoiding the material to stay in intimate contact with dentin. However, conclusions from this analysis must be carefully drawn out because of the variety on the intratubular tooth anatomy and also due to the methodology for preparation of specimens for SEM observation.

An interesting observation of our study was that the intratubular mineralization process was not limited to the biomaterial-dentin interface; it was possible to observe this phenomenon all over the dentin surface. It seems that the biomineralization process occurs simultaneously with dentin as with soft tissue, promoting an apatite layer that allows the integration of the biomaterial into the environment.

Dentin organic matrix possesses properties that can initiate and regulate crystal nucleation and thus, can control mineral growth $(20,21)$. It is well known that noncollagenous proteins present in the mineralized dentin matrix, such as dentin matrix protein 1 (DMP1), have a regulatory function in dentin formation. Recombinant DMP1 molecules have been thought to perform specific molecular recognition with the apatite surface, guiding calcium phosphate clusters during recruitment through the type I collagen matrix, which serves as a template for a controlled biomineralization $(4,10)$.

MTA and $\mathrm{Ca}(\mathrm{OH})^{2}$ have been shown capable of inducing mineralized tissue formation at different oral and dental tissue sites. A recent study suggested that MTA and $\mathrm{Ca}(\mathrm{OH})^{2}$ modulate dental tissue repair through their capacity to mobilize bio-active components of the dentin matrix $(1,22)$. The interaction of MTA and/or $\mathrm{Ca}(\mathrm{OH})^{2}$ with dentin causes growth factor and other bioactive molecule mobilization, which subsequently stimulates reparative events culminating in mineral tissue deposition $(1,22)$.

The biological basis for the clinical benefits of both MTA and $\mathrm{Ca}(\mathrm{OH})^{2}$ has yet to be completely elucidated. Therefore, this study demonstrated that simultaneous with the acute inflammatory response, a biomineralization process occurs. Thus, we hypothesize that the precipitation of apatite by MTA and $\mathrm{Ca}(\mathrm{OH})^{2}$ during the acute phase of inflammation together with the activation of NF-kB signaling pathway contributes to signal several unrecognized pathways in different cell types. Apatites may induce changes in gene expression and subsequently in cell functional activity, which are likely to contribute in repair and biomineralization process.

In conclusion, $\mathrm{MTA}$ and $\mathrm{Ca}(\mathrm{OH})^{2}$ when in contact with living tissues, promoted a biomineralization process with dentin. MTA triggered an earlier and denser interfacial layer. The biomineralization ability of MTA and $\mathrm{Ca}(\mathrm{OH})^{2}$ may induce repair and hard tissue deposition, allowing the integration of the biomaterial into the environment. 

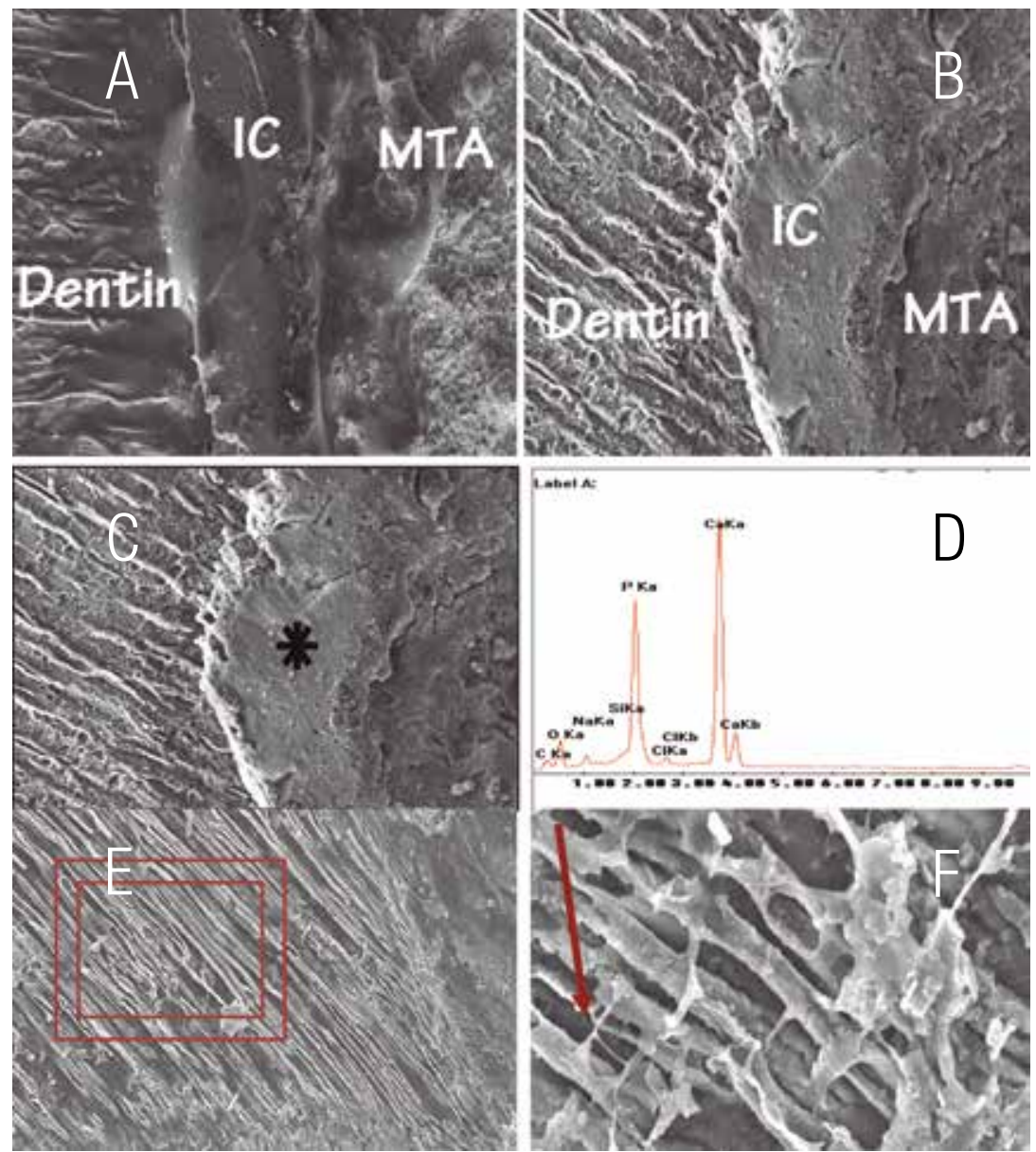

Figure 2. (A) SEM photomicrographs of ProRoot MTA-dentin interface, at $12 \mathrm{~h}$, and at $24 \mathrm{~h}$ post-implantation (B). (C, D) SEM-EDAX of the interfacial layer (IC) demonstrates that has different composition from MTA, composed primarily by $\mathrm{Ca}$ and P. (E) Observe the intratubular mineralization process all over the surface (2000X) and in (F) the mineralization of collagen fibers with lateral branches (5000X). 

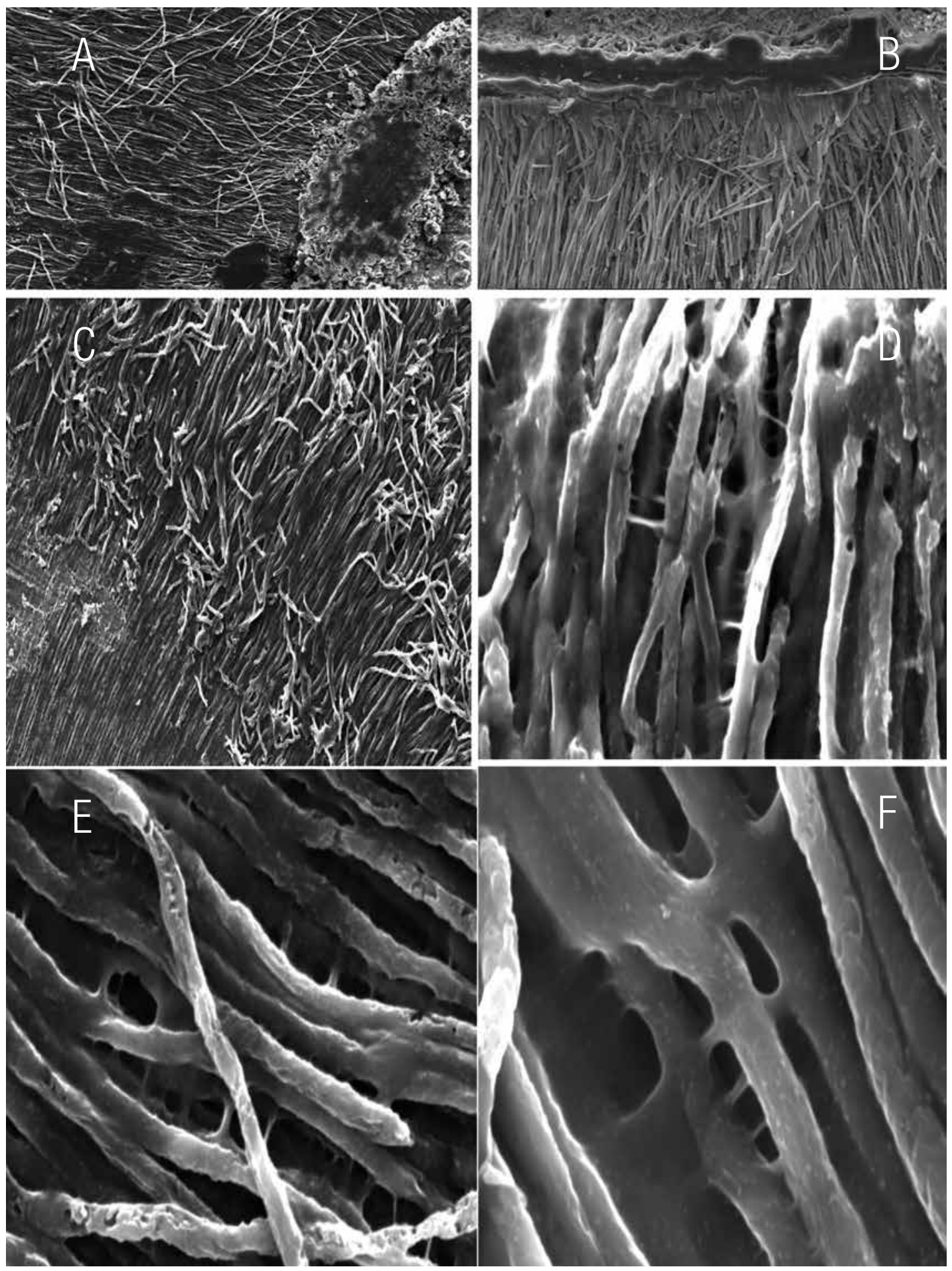

Figure 3. (A) SEM photomicrographs of ProRoot MTA-dentin interface, at 15 days and (B) 60 days after implantation. (C, D) Observe the intratubular mineralization process all over the surface and in (E, F) the formation of "tag-like structures" with lateral branches. 

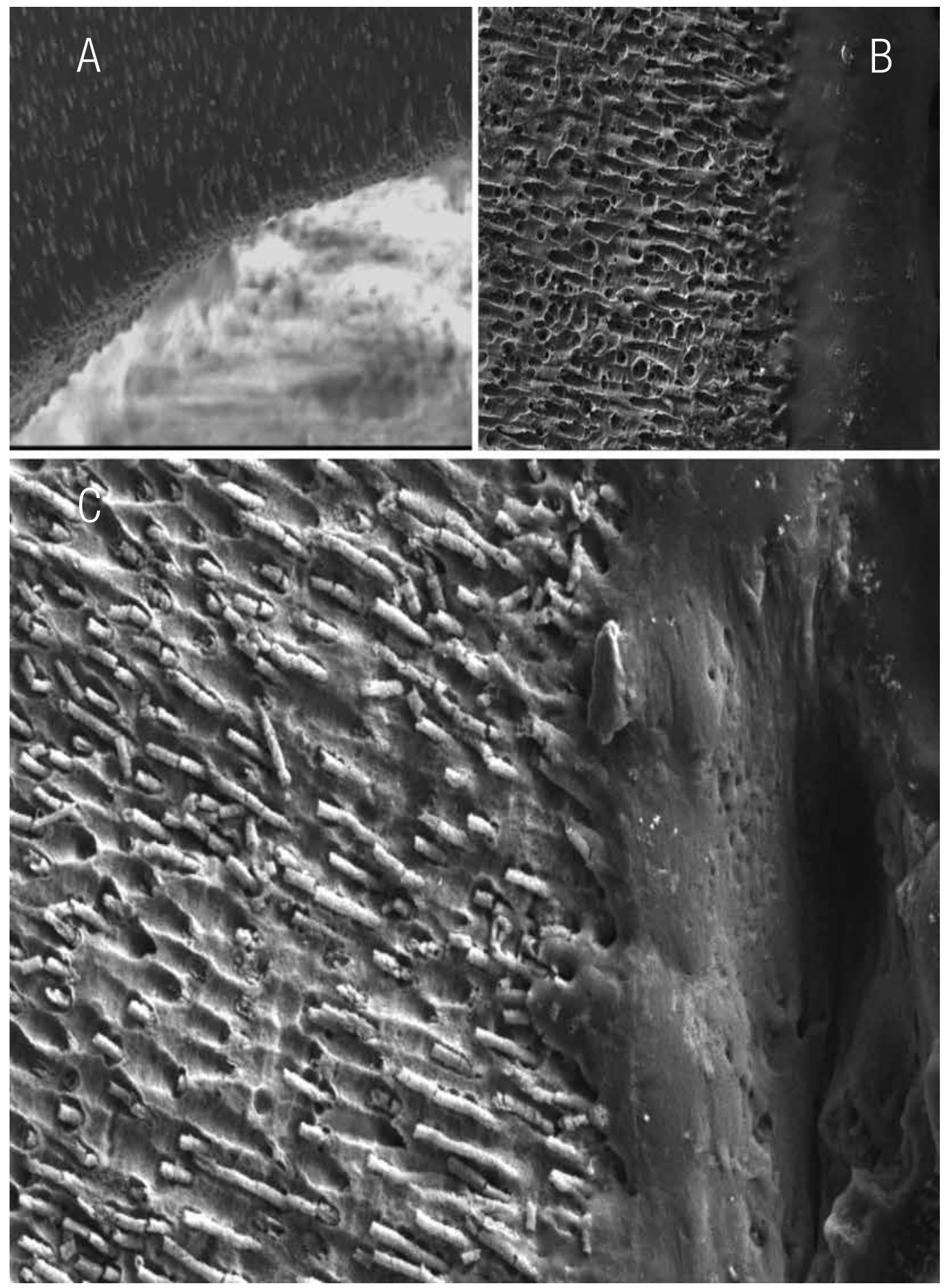

Figure 4. SEM photomicrographs of dentin tubes filled with Calcium hydroxide at $12 \mathrm{~h}(\mathrm{~A})$, and 7 days after implantation (B) (1500X). In higher magnification, it was possible to observe some tag-like structures at 60 days after implantation (C) Observe some mineralization process occurred in dentin tubules. 


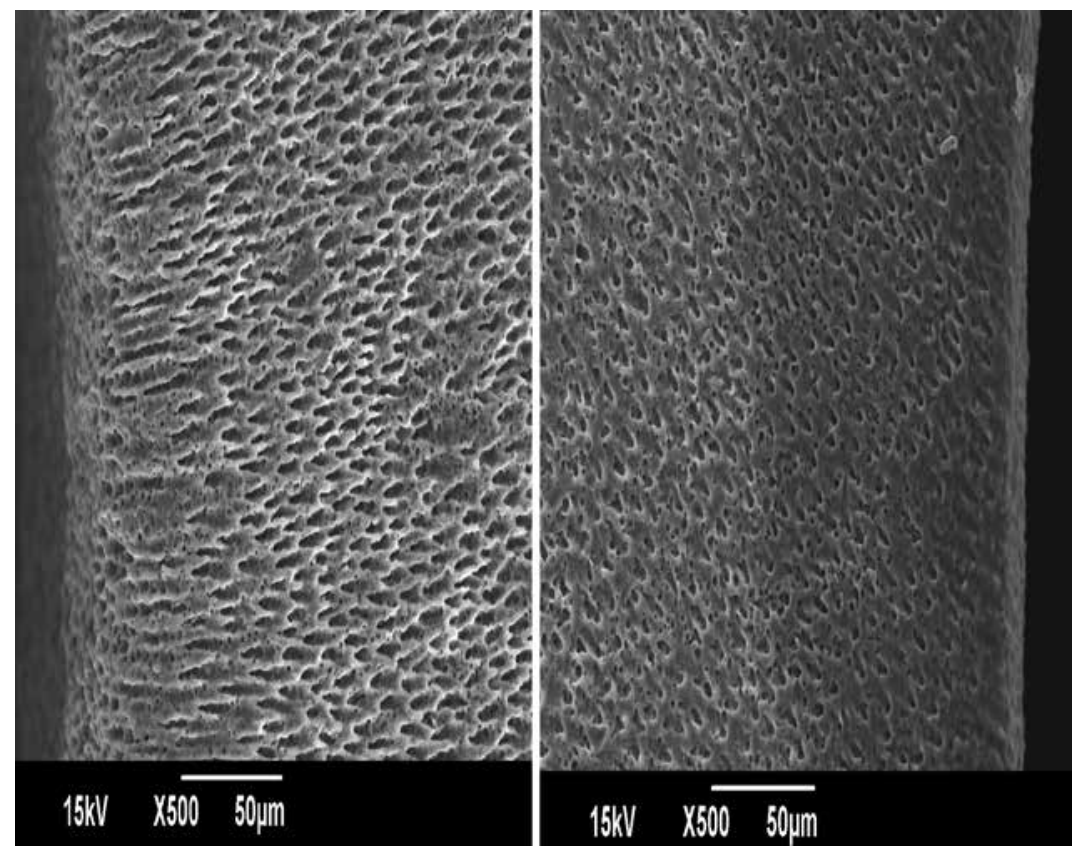

Figure 5. SEM photomicrographs of empty dentin tubes showing no mineralization.

\section{REFERENCES}

1. Thomson P. L., Grover L. M., Lumley P. J., Sloan A., Smith A. J., Cooper P. R. Dissolution of bio-active dentine matrix components by mineral trioxide aggregate. J Dent 2007; 35: 636-42.

2. Ferracane, J. L., Cooper, P. R., Smith, A. J. Can interaction of materials with the dentin-pulp complex contribute to dentin regeneration? Odontology 2010; 98: 2-14.

3. Tay F. R., Pashley D. H., Rueggeberg F. A., Loushine R. J., Weller R. N. Calcium phosphate phase transformation produced by the interaction of the Portland cement component of white mineral trioxide aggregate with a phosphate-containing fluid. J Endod 2007; 33:1347-51.

4. Reyes Carmona J., Felippe M. S., Felippe W.T. Biomineralization ability and interaction of Mineral Trioxide Aggregate and white Portland cement with dentin in a phosphatecontaining fluid. J. Endod 2009; 35:731-6.

5. Reyes Carmona J. F., Felippe M. C. S., Felippe W. T. The biomineralization ability of Mineral Trioxide Aggregate and Portland cement on dentin enhances the push-out strenght. J Endod 2010; 36: 286- 291.

6. Reyes Carmona J. F. et al. Host-Mineral Trioxide Aggregate Inflammatory Molecular Signaling and Biomineralization Ability. J Endod 2010; 36:1347-1353.

7. Holland R., de Souza V., Nery M. J., Otoboni Filho J. A., Bernabe P. F., Dezan J. E. Reaction of rat connective tissue to implanted dentin tubes filled with mineral trioxide aggregate or CH. J Endod 1999; 25:161-6.

8. Faraco I. M., Holland R. Response of the pulp of dogs to capping with mineral trioxide aggregate or a calcium hydroxide cement. Dental Traumatology 2001;17:163-6.

9. Dominguez M.S., Witherspoon D.E., Gutmann J. L., Opperman L. A. Histological and scanning electron microscopy assessment of various vital pulp-therapy materials. J Endod 2003; 29: 324-33.

10. Tay F.R., Pashley D.H. Guided tissue remineralisation of partially demineralized human dentine. Biomaterials 2008; 29: 1127-37. 
11. Huang, T. H. et al. Inflammatory cytokines reaction elicited by root-end filling materials. J Biomed Mater Res B Appl Biomater 2005; 73:123-8.

12. E.T. et al. Cellular response to Mineral Trioxide Aggregate. J Endod 1998; 24: 543-7.

13. Minamikawa, H. et al. Effect of Mineral Trioxide Aggregate on rat clonal dental pulp cells: expression of cyclooxygenase-2 mRNA and inflammation-related protein via nuclear factor kappa B signaling system. J Endod. 2009; 35: 843-6.

14. Chen, C. L., T. H. Huang, S. J. Ding, M. Y. Shie and C. T. Kao. Comparison of calcium and silicate cement and mineral trioxide aggregate biologic effects and bone markers expression in MG63 cells. J Endod 2009; 35: 682-5.

15. Hakki, S. S., S. B. Bozkurt, E. E. Hakki and S. Belli. Effects of mineral trioxide aggregate on cell survival, gene expression associated with mineralized tissues, and biomineralization of cementoblasts. J Endod 2009; 35: 513-9.

16. Holland R. et al. Calcium salts deposition in Rat connective tissue alter the implantation of CH-containing sealers. J Endod 2002; 28 : 173-6.

17. Bohner M., Lemaitre J. Can bioactivity be tested in vitro with SBF solution? Biomaterials 2009; 30: 2175-9.

18. Sarkar N. K., Caicedo R., Ritwik P., Moiseyena R, Kawashima I. Physiochemical basis of the biologic properties of mineral trioxide aggregate. J Endod 2005;31:97-100.

19. Bozeman T.B., Lemon R.R., Eleazer P.D. Elemental analysis of crystal precipitate from gray and white MTA. J Endod 2006; 32: $425-8$.

20. LeGeros R.Z. Calcium phosphates in oral biology and medicine. In: Myers HM, ed. Monographs in oral science 15. Basel, Switzerland: Karger; 1991: 4-66.

21. Veis A. Mineral- matrix interactions in bone and dentin. J Bone Miner Res 1993;8(Suppl. 2): S493-7.

22. Graham L., Cooper P. R., Cassidy N., Nor J.E., Sloan A.J., Smith A.J. The effect of $\mathrm{CH}$ on solubilisation of bioactive dentine matrix components. Biomaterials 2006; 27 : 2865-73. 